\title{
THE ROOTS OF REDS: A RATIONALE FOR THE SUPPORT OF EDUCATORS AFFECTED BY THE HIV AND AIDS PANDEMIC
}

\author{
Prof. Linda Theron \\ DEd (Educational Psychology)
}

Associate Professor, School of Education Sciences, North-West University (Vaal Triangle campus)

Corresponding author: linda.theron@nwu.ac.za

\author{
Dr Stephan Geyer \\ $\mathrm{PhD}$ \\ Lecturer, Department of Social Work and Criminology, University of Pretoria, Pretoria
}

\section{Prof. Herman Strydom \\ $\mathrm{PhD}$ \\ Professor, Head of Department, School for Psychosocial Behavioural Sciences: Social Work Division, North-West University (Potchefstroom campus)}

\section{Prof. CSL Delport}

D Litt et Phil

Associate Professor, Department of Social Work and Criminology, University of Pretoria

Keywords: HIV-affected; educators; support programme; resilience

\begin{abstract}
The nature of educators' work has changed dramatically, in part because of the challenges of the HIV and AIDS pandemic. Despite these multiple and relentless challenges which educators contend with, and despite numerous calls for educator empowerment to cope with HIV -related challenges, little has been done up until now to support educators. By reviewing current literature, this article outlines the HIV-altered professional reality of South African educators and makes the argument that affected educators need support to cope. In conclusion, the support programme, Resilient Educators (REds), is introduced as one possible means of educator support.
\end{abstract}

\section{OPSOMMING}

Die aard van onderwysers se werk het dramaties verander, deels as gevolg van die uitdagings van die MIV-en Vigspandemie. Ten spyte van hierdie veelvoudige en onverbiddelike uitdagings waarmee onderwysers gekonfronteer word, en ten spyte van die talle oproepe tot onderwyserbemagtiging om die MIV-verwante uitdagings die hoof te bied, is daar tot dusver min gedoen om onderwysers te ondersteun. Deur middel van 'n literatuuroorsig beskryf hierdie artikel die MIV-veranderde professionele werklikheid van Suid-Afrikaanse onderwysers en word daar geargumenteer dat geaffekteerde onderwysers ondersteuning nodig het om die situasie te hanteer. Gevolglik word die ondersteuningsprogram "Resilient Educators (REds)" voorgestel as moontlike wyse van onderwyserondersteuning. 


\section{INTRODUCTION}

Worldwide the nature of the educator's work is changing (Hall, 2004:5), and the contexts in which teaching occurs progressively regulate educator identity and educator activity (Hoadley, 2002:42-43) and, ultimately, educator health. Increasingly, educators in the Western world are expected to respond to situational and relational macro- and micro-trends within their societies (Hall, 2004:4-12). This is true of educators in South Africa, too (Le Grange, 2008).

One of the consequences of these multiple, unrelenting changes is that educators' tasks have intensified, leaving educators in need of a concomitantly advanced repertoire of skills (Hall, 2004:3). Often this repertoire includes caring for children, even more so when the social reality in which education occurs is impacted by vicissitudes of the HIV and AIDS pandemic. Worldwide, educators report feeling careworn and dispirited (Hall, 2004:9). South African educators, including those affected by the HIV and AIDS pandemic, report similar stressful and burdening experiences (Bhana, Morrell, Epstein \& Moletsane, 2006:5-8; Hall, Altman, Nkomo, Peltzer \& Zuma, 2005:27; Schulze \& Steyn, 2007:691; Theron, 2007a:175). Many South African educators considering quitting the teaching profession cite the challenges of teaching in an HIV-altered reality as one of the factors motivating their attrition (Hall et al., 2005:27).

This article focuses on how the HIV and AIDS pandemic has changed the nature of South African educators' work and notes that little has been done to empower educators to cope with their HIV-altered educational reality, despite a robust call for such support (Bennell, 2005:460-462; Bhana et al., 2006:18-19; Coombe, 2000; Coombe, 2002; Coombe, 2003:10; Hall et al., 2005:30; Kinghorn \& Kelly, 2005:497-498; Shisana, Peltzer, Zungu-Dirwayi \& Louw, 2005; Simbayi, Skinner, Letlape \& Zuma, 2005; Theron, 2005:56; Theron, 2007a:175). This changed demand of teaching in a context of HIV and AIDS and the lack of support for affected educators are used as rationale for the concept of the Resilient Educators (REds) support programme (Esterhuizen, 2007; Theron, 2007a:184; Theron, 2008:34), which will be outlined briefly at the end of this article.
The above focus is facilitated by a review of current literature on the nature of teaching within an HIV and AIDS-altered educational reality and efforts to support educators to cope with this. The central argument of this article is that HIV and AIDS have radically altered the job description of South African educators and that affected educators need support to cope with this.

\section{THE IMPACT OF THE HIV AND AIDS PAN- DEMIC ON AFFECTED EDUCATORS}

The cogent call for the support of South African educators affected by HIV and AIDS (Bennell, 2005:460-462; Bhana et al., 2006:18-19; Coombe, 2000; Coombe, 2002; Coombe, 2003; Hall et al., 2005:30; Kinghorn \& Kelly, 2005:497-498; Shisana, Peltzer, Zungu-Dirwayi \& Louw, 2005; Simbayi et al., 2005; Theron, 2005:56; Theron, 2007a:184) is related to the belief that HIV and AIDS have radically altered teaching for many South African educators. This altered educator experience is related to educators being affected by colleagues, learners and/or family members being HIV positive, or dying from AIDS-related illnesses, or to teaching AIDS orphans and learners made vulnerable by the HIV pandemic (Hall et al., 2005:23-24). Although not all researchers would agree (Bennell, 2005:442-445; Shisana, Peltzer, Zungu-Dirwayi \& Louw, 2005), Coombe (2003) is convinced that no educator is unaffected by the HIV and AIDS pandemic.

When educators are affected, they report mainly distressing impacts. A photovoice study conducted with 40 educators in KwaZulu-Natal suggested that they experienced the impacts of HIV as a "traumatic journey" (De Lange, Mitchell, Moletsane, Stuart \& Buthelezi, 2006:51) and that HIV and AIDS had become a "heavy load" (De Lange et al., 2006:59) for educators.

The professional demands on affected educators are described as generally taxing (Bhana et al., 2006:717; Coombe, 2003; Theron, 2007a:177; Theron, 2008:33-34). In brief, the professional demands encompass raising HIV and AIDS awareness, teaching prevention, aiding infected and affected learners (and even colleagues), shouldering increased teaching loads as infected colleagues are increasingly absent, and coping with the ordeal of HIV-related sickness and death in significant others (Bhana et al., 2006:7-18; Car-Hill, 
2003; Coombe, 2003; Theron, 2007a:177; Theron, 2008:33-34).

What emerges strongly from the literature on professional demands is that affected educators are severely challenged by caregiver demands. In 2005, 14,4\% of all children between the ages of 2 and 18 were identified as orphans (Shisana, Rehle, Simbayi, Parker, Zuma, Bhana, Connolly, Jooste \& Pillay, 2005:112), and so educators are increasingly distressed by the large numbers of learners made vulnerable by HIV and AIDS (Bhana et al., 2006:14-18; Boler, 2003). Many of these vulnerable learners need more than didactic lessons most have additional (often unmet) needs such as grief counselling, hunger, accommodation and school fees; most need support to cope with discrimination, abuse, rejection, lost childhoods, and so forth (Bhana et al., 2006:14-18; Coombe, 2003; Ebersöhn \& Eloff, 2002:7879). At many schools, there is an absence of professionally trained staff to respond to the HIV-related needs of learners, and so educators have to fill this gap, often without the necessary knowledge, skills, or support systems (Bhana et al., 2006:8; Coombe, 2003; Hoadley, 2007:254-256; Theron, 2007a:181). Many educators represent the lone source of hope, information and/or comfort for learners or community members affected by, or infected with, the pandemic. Provincial departments of education often lack the human resources to provide counselling or underspend funds earmarked for support and care of HIV-affected learners (Govender, 2008). Many learners only have educators to turn to, as they have no or inadequate access to mental health service providers and social services (Theron, 2007b:181). The net result is often beleaguered educators (Hall et al., 2005; Hoadley, 2007:252-254; Kendall \& O'Gara, 2007:17; Theron, 2008:33-34; 37). Education authorities erroneously presupposed that educators could play caregiver roles, but in effect educators bemoan inadequate preparation and support in this regard (Bhana et al., 2006:20; Coombe, 2003).

When educators teach in rural schools where the HIV pandemic magnifies the contextual barriers that learners face, the burden of care that educators shoulder is more acutely felt (Bhana et al., 2006:8). In underresourced schools, the educator often needs to be 'all things to all people' (for example, social worker, counsellor, caregiver, advisor, educator), which contributes to many educators becoming overinvolved with learn- ers (Bhana et al., 2006:14-16; Hoadley, 2007:257; Theron, 2007a:181). Often, care work related to multiple educator roles thwarts effective teaching (Bhana et al., 2006:14-16; Hoadley, 2007:252-253; Theron, 2007a:177) and creates stressful time management problems for educators (Theron, 2007a:180).

The mandate to care for learners (Morrow, 2007) is not limited to South African educators. In Africa, the Nairobi Cluster Consultation (Nkinyangi, 2003) identified two central education tasks in response to the pandemic, the second of which was to use education to mitigate the impacts of the pandemic by teaching prevention and by providing care and support for those affected by HIV and AIDS. In this regard, one of the education sector's chief responsibilities was described as "The provision of basic social and psychological support to learners and educators affected and infected by HIVIAids" (Nkinyangi, 2003:6). With regard to basic social support, educators were considered to be responsible for providing basic counselling support and referral and for providing safe and secure learning environments, which includes caring for those affected by HIV and AIDS.

In addition to being exhausted by the demands for care, many educators are also stressed by departmental expectations that they function as prevention agents and teach safer sex and HIV prevention (Bhana et al., 2006:7; Car-Hill, 2003; Coombe, 2003). This expectation is not specific to South Africa: worldwide, educators are expected to educate learners about HIV and AIDS. For example, in the Western Balkans, which has one of the fastest growing HIV epidemics, schoolbased education has been identified as a prevention method (Godinho, Jaganjac, Eckertz, Renton \& Novotny, 2005). In Germany, compulsory HIV education is presented to teenagers as part of their school curriculum (Winkelmann, 2006). In the USA, most states have mandatory HIV and AIDS education as part of the curriculum, and high school educators are often expected to support students affected by, or infected with, the virus (Dawson, Chunis, Smith \& Carboni, 2001:3; Raj, Decker, Murray \& Silverman, 2007:192). Earlier research suggested that some American educators were uncomfortable with this role (Boscarino \& DiClemente, 1996) and that at least two-thirds of educators surveyed believed educators needed more HIVand AIDS-related training (Dawson et al., 2001: 7). Later 
research reconfirmed the need for more HIV- and AIDSrelated training for educators (Dawson et al., 2001:78). Similarly, a South African study found that sampled high school educators felt only moderately comfortable teaching about HIV and AIDS and that at least 25\% held misconceptions about HIVIAIDS, which suggested inadequate HIV-and AIDS-related knowledge. The same study noted that educators reported scant material resources and community support (that is, from religious groups and parents) with regard to prevention education (Peltzer \& Promtussananon, 2003:354). Many South African educators are uncomfortable with their enforced role of prevention agents, in part because of inadequate training (Car-Hill, 2003; Coombe, 2003; Peltzer, 2000 in Peltzer \& Promtussananon, 2003:351).

The impacts of the HIV pandemic are not necessarily limited to the ensuing professional challenges. Many educators may themselves be infected (Hall et al., 2005:23) or may know, love, or be related to people infected with the HI virus. Many educators may have buried, or be grieving for, significant others who died from AIDS-related complications. Emotional lability, depression, fear and general despair are often associated with such personal impacts (Bhana et al., 2006: 5; Coombe, 2003; Kinghorn \& Kelly, 2005:493; Theron, 2005:58; Theron, 2007a:179).

In summary, educators are often overwhelmed by the professional and personal impacts of living and teaching in an HIV-altered milieu. Many are engulfed by emotional and spiritual distress (Theron, 2007a:178-180) and progressively floundering professional morale and performance (Hall et al., 2005:25). Their plight is affirmed by the repeated calls for the empowerment of affected educators (Bennell, 2005:460-462; Bhana et al., 2006:20; Coombe, 2000; Coombe, 2002; Coombe, 2003; Hall et al., 2005:30; Kinghorn \& Kelly, 2005:497498; Shisana, Peltzer, Zungu-Dirway \& Louw, 2005; Simbayi et al., 2005; Theron, 2005:59; Theron, 2007a:183-184).

\section{INTERNATIONAL, REGIONAL AND LO- CAL RESPONSES TO THE PLIGHT OF AF- FECTED EDUCATORS}

Internationally, within Africa, and nationally, governments and societies have realised that the current HIV and AIDS pandemic poses a grave challenge to communi- ties with regard to their ability to sustain functional social welfare. As a result, various commitments, initiatives and policies have been forwarded to manage the impact of HIV and AIDS in general, including their impacts on education and educators.

\section{International response}

In America, there has been a continued drive to assess educators' AIDS-related knowledge and attitude and to educate educators (Dawson et al., 2001:3-4). This was, and is, done in recognition of the value of in-service training, especially with regard to its advantageous impact on educator attitude and response to HIV and AIDS and the concomitant benefits for school-going youth. In the Philippines, HIV education at secondary and tertiary level is enforced by government and supported by a plethora of non-government organisations (NGOs) (Mateo, Sarol \& Poblete, 2004:49), but no mention is made of support for affected educators.

In developing countries, there is an internationally driven crusade to promote education for all and to stem HIV. In 1995, during the United Nations' World Summit for Social Development in Copenhagen, a large number of developing countries adopted social development as an approach to build up their countries. Subsequently, ten principal commitments to promote social development were adopted (International Council on Social Welfare [ICSW], 1995:9-16). Commitment 6 aims to achieve "... universal and equitable access to quality education ..." (ICSW, 1995:11), while Commitment 7 specifically targets the African continent by aiming "... to ensure that HIVIAIDS ... do not restrict economic and social development" (ICSW, 1995:12). In 2000, these commitments were streamlined into measurable goals through the formulation of eight Millennium Development Goals (MDGs) (Zammit, 2003:3-4). Goal 2 aims to ensure that, by 2015 , both males and females will be able to complete a full course of primary schooling, while Goal 6 aims to halt the spread of HIV and AIDS. From these international initiatives, it is clear that attending to HIV- and AIDS-related issues affecting people's social functioning and the importance of schooling to achieve optimal social development are not negotiable. However, the goals do not specifically acknowledge or address the plight of affected educators. 


\section{Regional response}

As globalisation continues to shrink our world (Castells, 1998: 6-7), the African continent is under pressure to respond to the international community's decision to adopt social development as a strategy to address social problems such as HIV and AIDS and inadequate education. Consequently, two of the African Union's objectives link directly to the aforementioned challenges of HIV and AIDS, and poor education (cf. Republic of South Africa, Department of Foreign Affairs, 2004). Specifically within southern Africa, the need to address these two social problems is severely felt. As a result, the Southern African Development Community (SADC) established a programme to deal explicitly with health problems, such as HIV and AIDS, as well as a programme to improve education on the continent (cf. Patel, 2005:44-61). The success of these programmes is dubious should educators not be empowered to provide quality education notwithstanding the challenges they experience daily owing to, among other things, the AIDS pandemic.

In Africa, the typical response to the HIV pandemic has included both curricular and extra-curricular learnerfocused educational initiatives that encourage HIV prevention with some emphasis on the need to provide educators with relevant training and policy to cope in this regard (Campbell \& Lubben, 2003; Jacob, Mosman, Hite, Morisky \& Nsubuga, 2007:114-115). Nevertheless, in Namibia, the study by Campbell and Lubben (2003) noted a pervasive lack of school health policy documents to frame HIV education and inadequate HIV-related educator training. In Uganda, the study by Jacob et al. (2007:116) noted that HIV education did not actually take place, partly because at least $75 \%$ of educators had not received related training. During the Nairobi Cluster Consultation (Nkinyangi, 2003), delegates were concerned that the African countries involved (Rwanda, Burundi, Kenya and Uganda) were paying insufficient attention to issues of care and support. Only Burundi and Kenya had acknowledged the need for HIVand AIDS-related educator trauma to be dealt with. The Consultation's way forward was to note the need to revise pre-service and in-service educator preparation for care and support. There was no specific mention of the need to support educators.

\section{Local response}

The South African government responded to the ten principal commitments formulated in Copenhagen (Midgley, 2001:267-270), as well as the programme formulations of the African Union and SADC, to address HIV- and AIDS-related problems, as well as education. Since South Africa's democratisation in 1994, various policies, strategies and legislation have been promulgated to promote South Africa's progress towards reconstruction and development (Matube, 2005:173-186). The South African Constitution of 1996 declares access to health services to deal with, among other things, HIV and education as fundamental rights. Implicit in the constitutional framework is the support needs of HIV- and AIDS-affected educators if they are to provide quality education to the learners in this country. Nevertheless, although South African authorities, NGOs and service providers have, in the main, engaged actively with the challenge to support South Africans who are impacted by HIV and AIDS (for example, prevention programmes, fiscal projections, awareness campaigns), very little of this support is channelled towards affected educators (Mitchell et al., 2005:258). As in Africa and America, the South African response has been to endorse educators doubling as caregivers and prevention agents, by producing policy and providing training.

As in America (Dawson et al., 2001:3-4), in-service training of educators is recognised as a means to empower educators to feel more in control of HIV and AIDS education and encouraged for South African educators (Peltzer \& Promtussananon, 2003:355). Bhana et al. (2006:11-12) assert that few educators are adequately trained to cope with the stringent demands of prevention teaching or educator caring associated with the pandemic. In 1997, about 10000 educators were trained by the Department of Education to teach HIV- and AIDSrelated life skills (Peltzer \& Promtussananon, 2003:350). However, it was noted that this training was not completely successful (Harrison, Smit \& Myer in Peltzer \& Promtussananon, 2003:350). Furthermore, some schools still report training of only a limited number of their educators and that many educators remain uncomfortable about teaching HIV-related curricula (Govender, 2008). Continued training and support are obstructed by some provincial education departments' failure to spend government grants earmarked for addressing HIV and AIDS (including educa- 
tor training and establishing care and support groups for learners made vulnerable by the pandemic) (Govender, 2008).

Pre-service training for aspirant educators has been acknowledged as a powerful means of supporting future educators. One response to this has been the Higher Education Aids (HEAIDS) project (Piloting of HIV module in educator education facilities in the higher education institutions in South Africa) (HEAIDS, 2007), under the auspices of Higher Education South Africa. This project aims to provide student educators with participative pedagogical approaches to HIV teaching, an understanding of how social and economic issues relate to HIV and AIDS, insight into the physical, economic, social and emotional impact of the HIV and AIDS pandemic on educators, learners and their communities, and the skill to respond sensitively, positively and holistically to the practical and psychosocial needs of learners and colleagues (HEAIDS, 2008). The vast majority of the 23 higher education institutions are currently participating in this project, which is projected to end in May 2009. The impact of the project, especially its effectiveness in supporting aspirant educators to cope with an HIV-altered teaching reality, can only be reported once the project has been concluded.

The National Policy on HIV and Aids for Learners and Educators in Public Schools and Students and Educators in Further Education and Training Institutions spells out the official Department of Education (DoE) HIV- and AIDS-related policy regarding supportive service conditions, discrimination, prevention and support for those who are ill, and a proactive, humanitarian response to the HIV and AIDS pandemic (Simbayi et al., 2005). Hoadley (2007:251-252) lists further policies largely concerned with helping schools cope with the pandemic, especially its impact on orphaned or vulnerable learners, including:

- $\quad$ The HIVIAIDS emergency: Guidelines for educators (2000)

- $\quad$ HIV and AIDS: Care and support for affected and infected learners: A guide for educators (2001)

- National Integrated Plan for Children and Youth Infected and Affected by HIVIAIDS (2001)

- National School Health Policy and Implementation Guidelines (2002)

- National School Nutrition Programme (2002)
- Implementation Plan for Tirisano, January 2000 - December 2004 (2003)

- Education Laws Amendment Bill (2005)

Although there are clearly numerous HIV-related policies, some educators are inclined to respond individually and, therefore, variably to policy (Bhana et al., 2006:8; Hoadley, 2007:254), thereby potentially undermining how supportive policy is in reality. Xaba (2008: 112-114) maintains that affected educators are supported through policies in that these provide information regarding educator rights, encourage educator HIV awareness and healthy living, and promote supportive working conditions. However, a study by Hartell and Maile (2004: 198) noted that policy guiding supportive and non-discriminatory practices was not always effectively implemented or monitored.

South Africa's major educator unions, the South African Democratic Teachers' Union (SADTU) and the National Professional Teachers' Organisation of South Africa (NAPTOSA), endorse the supportive policies of the DoE (Simbayi et al., 2005; UNESCO \& EI-EFAIDS, 2007). SADTU's policy attempts to empower its members to understand and manage the impact of the HIV and AIDS pandemic and to protect its members against discrimination (Simbayi et al., 2005). NAPTOSA's policy targets prevention via advocacy of awareness and support programmes (Simbayi et al., 2005).

As outlined in the DoE's policy on inclusive education (2001), educators can rely on within-school support services (school support teams or SSTs) and extraschool support services (district support team) (Donald, Lazarus \& Lolwana, 2007: 25). The primary rationale of SSTs and district support teams is to provide support to overcome barriers and issues (including HIV) that could thwart effective teaching and learning (Adelman \& Taylor, 2003; Donald et al., 2007: 25; Johnston, 2005:43). In reality, many educators report being dissatisfied with the support that they receive and note that accessing district support is often challenging (Johnston, 2005:309). To the best of our knowledge, there are no documented support programmes or initiatives for educators grappling with effective and inclusive education when the latter is made more difficult by HIV and AIDS, despite the aforementioned DoE policy.

There are incidences of support for affected educators 
in the form of South African research initiatives. Within the South African context of educators who are negatively affected by HIV and AIDS, some researchers responded positively to the challenge of research as a tool to promote social change and upliftment (Schratz \& Walker, 1995) and devised research projects that included educator empowerment towards better coping with HIV and AIDS.

One such project was the "Learning together project" carried out in the Vulindlela district in KwaZulu-Natal. The main purpose was to address the day-to-day realities of HIV and AIDS in South Africa by encouraging educators and health care workers to cooperate (De Lange, 2008:182; Mitchell et al., 2005:259). The project equipped participants with a deeper awareness of the pandemic and a realisation that they needed to share ideas and communicate from multidisciplinary perspectives as a community (De Lange, 2008:182182). Participants realised that community synergy would help to manage HIV and AIDS in schools (Mitchell et al., 2005:267-268).

Another empowering research initiative was conducted in an Eastern Cape school located in an informal settlement community where the incidence of HIV and AIDS is high (Ferreira, 2007:380-388). The project aimed to help the community, including educators, to cope with HIV and AIDS using an asset-based intervention approach as introduced by Kretzmann and McKnight (1993). Participants were encouraged to map, mobilise and access community assets that could be used to cope with the challenges of the HIV pandemic (Ferreira, 2007:380-388). One spin-off of this initiative was three school-based projects, including a school-based vegetable garden, an information centre and a support group for infected and affected people from this community (Ferreira, 2007:380-388).

In summary, similar to international and regional responses to the plight of educators affected by HIV and AIDS, our national response is largely limited to preservice and in-service training and to the provision of policy. Additional support for affected educators (such as in that discussed under De Lange's and Ferreira's research projects) does not appear to be large scale or formally coordinated. This has significant implications for practice. In essence, Goals 2 and 3 of the MDGs (Zammit, 2003:3-4) are imperilled, given this lack of international, regional and national support for affected educators. The development of a programme addressing the support needs of HIV- and AIDS-affected educators will ultimately contribute to sustaining quality education and health promotion and could therefore be regarded as an indirect contribution towards the realisation of social development in developing countries such as South Africa.

\section{IMPLICATIONS FOR PRACTICE}

There is some merit in the argument that South African schools may need to be more than sites of teaching and learning, given South Africa's manifold social problems (DoE, 2000; Donald et al., 2007:28; Hoadley, 2007:257-258) - within this reality, schools and educators do need to conceptualise education and service delivery more broadly (Hoadley, 2007:253; Johnston, 2005:339-340; Pridmore \& Yates, 2005:510). As noted, one consequence of an HIV- and AIDS-affected context has been the growing demand on educators to be more than educators in the traditional sense of professionals who engage pedagogically and didactically with learners. In an HIV- and AIDS-affected context, educators are challenged to double as HIV-prevention agents, counsellors, social workers and even surrogate parentfigures (Bhana et al., 2006:7; Coombe, 2003; DoE, 2000; Hoadley, 2007:256; Theron, 2007a:177). The most prevalent response to this challenge is to provide preservice and in-service training and script policy, neither of which has been adequate as a means of supporting educators to rise resiliently to the challenges of an HIValtered teaching context (Bhana et al., 2006:8; Govender, 2008; Hartell \& Maile, 2004:198; Hoadley, 2007:252).

The implication for practice is clear: South African educators need comprehensive support to cope with the challenges of a professional role that has been escalated to encompass HIV prevention, counselling and social work. To the best of our knowledge, there is no form of comprehensive support for affected educators, although some South African research initiatives have empowered participating educators and their communities (De Lange, 2008:182-183; De Lange et al., 2006:47; Ferreira, 2007:380-388; Mitchell et al., 2005: 267-268). This apparent shortcoming prompted our compilation of an interactive, participatory support programme entitled Resilient Educators (REds). 


\section{Resilient Educators (REds)}

REds has the express aim of empowering affected educators to cope more resiliently with the challenges of the pandemic by supporting educators to respond adaptively to a teaching context that demands responses more typical of counsellors, or social workers, or medical personnel trained to prevent HIV. With this in mind, the contents of REds were initially compiled by a multidisciplinary team that included a registered and practising educational psychologist, a nursing sister and an education management specialist. The contents were informed by academic resources (e.g. articles, textbooks), government documents (e.g. policy documents, legal documents, the South African Constitution), NGO publications, the popular press and documented community resources (e.g. community referral networks). The contents were grouped into nine modules, each of which provides thematic structure, background information and interactive activities for a single session of approximately 150 minutes. The contents of REds are printed in English as a ring-bound, user-friendly programme of approximately 200 pages and each participant receives a copy to use and keep. In addition, there is a facilitator's manual of approximately 60 pages (also in English and ring-bound) which each facilitator receives during training as a guide to REds facilitation.

In general, REds explores the themes of health promotion, the psychosocial impacts of the HIV pandemic on educators and learners, psychosocial supports (resources and skills), stigma and discrimination, HIVrelated education policy and resilience. These themes are developed in programme contents that include the biomedical facts of HIV and AIDS, practical guidelines on HIV prevention, practical guidelines on nursing people with AIDS-related illnesses, tips on using social networks, government grants and non-governmental structures to give and gain psychosocial and socioeconomic support, inventories of local, provincial and national supportive resources (e.g. hospice centres, clinics that provide anti-retroviral medication, local counsellors and supportive religious organisations), grief counselling skills, guidelines for educators confronted by grieving learners, the use of memory boxes, guidelines for coping with and minimising HIV-related discrimination, information on HIV-related education policies, stress management skills, time management skills and resilience skills and strategies. All of the aforementioned are explored within the confines of the participants' context (so, for example, instead of informing participants about the impacts of the pandemic on educators, they are encouraged to define how the pandemic impacts them and their communities). Participant knowledge and experiences are then supplemented by documented definitions, theories and recommended practices compiled from existing literature, therapeutic programmes and online resources. In addition, REds includes poems, inspirational quotes and narratives to embellish thematic foci.

In recognition of flagging educator morale (Hall et al., 2005:23-24) the social isolation of many affected educators (Theron, 2007a:179-180), and limited educator time (Schulze \& Steyn, 2007:693; 703-704; Theron, 2007a:180), REds was conceptualised as a group support programme that relies on active participation of participants and one that can be implemented flexibly according to participant time restraints (for example, over a weekend, weekly, biweekly). Group therapy has powerful therapeutic potential in the sense that groups facilitate a sense of belonging and psychological comfort (Ferreira, 2004:344-5).

As noted in the earlier discussion of South African research initiatives that empowered educators to cope better within an HIV-beleaguered context, the use of participatory approaches seemed intrinsic to participant empowerment (De Lange et al., 2006:61; Ferreira, 2007:380-388; Mitchell et al., 2005:259-260). For this reason, and also because REds respects that community members who take part in research are always co-contributing participants rather than research subjects (Swart \& Bowman, 2007:437), REds endorses a participatory approach. REds participant activities include reflection, compiling and sharing inventories of community resources, art therapy, music therapy, gestalt work, role play, visualisation, debate and discussion.

To date, REds has been implemented in four South African provinces with small groups of volunteer educator-participants in different communities. REds facilitators were trained by experienced researchers to facilitate the content and participatory group process of REds. After each implementation, REds was further developed according to participant and facilitator feed- 
back regarding how well REds facilitated resilient coping with the challenges of the HIV crisis. As part of this developmental process, an independent South African educational psychologist critically reviewed both the contents and process of REds. In practice, this meant that REds evolved. Some of these developments entailed extending REds to include an additional session, amending REds contents to be more culturally sensitive, altering the sequence of the modules, including more information and activities that focused on learner grief and simplifying the wording of the printed contents.

Currently, REds is being implemented with further groups of volunteer educators as part of continued iterative, intervention research to promote affected educator empowerment and support, and to standardise REds within the South African educational context (the latter relates to the future aim of disseminating REds to education departments and educators throughout South Africa). This makes REds research in process and implies that its contents and process may be further fine-tuned in order to optimalise it as an intervention tool that promotes educator health in spite of the relentless challenges of the HIV crisis.

\section{CONCLUSION}

The reality confronting educators in South Africa (and in other countries with a high HIV incidence) is HIV altered. One consequence of this is transmuted educator roles and relentless educator challenges. The sad reality is that many educators are negatively impacted by this (Bennell, 2005:478; Bhana et al., 2006:7-8; Coombe, 2000; Coombe, 2002; Coombe, 2003; Govender, 2008; Hall et al., 2005:25; Kinghorn \& Kelly, 2005:493; Shisana, Peltzer, Zungu-Dirwayi \& Louw, 2005; Simbayi et al., 2005; Theron, 2005:58; Theron, 2007a:182) and that little is done to support educators to cope more resiliently.

If we acknowledge that teaching and educator roles are context shaped (Hall, 2004:4; Hoadley, 2007:254; Le Grange, 2008), then we may no longer neglect the support of educators affected and challenged by HIV and AIDS. If we support the MDGs, we are challenged to support educators impacted by the HIV crisis. It is therefore vital that more service providers, departments of education and researchers initiate supportive interventions for educators such as the ongoing American in-service interventions (Dawson et al., 2001:7), empowering research projects such as those of De Lange et al. (2006) and Ferreira (2007), and potentially supportive interventions such as REds. Johnston (2005:38) makes the point that no learner can be described as at risk, but rather that many learners are placed at risk by various realities and choices. The same applies to educators: by merely calling for their support, providing inadequate training, writing policy without monitoring its implementation, or failing to orchestrate robust and ongoing support, we place South Africa's educators at risk. We expect a "culture of compassion" (Stuart, 2004:5) from our educators; it is time that we extend the same to them. In the final analysis, it is the duty of South African academics, researchers, service providers and education stakeholders to actively support affected educators towards a new repertoire of professional skills (Hall, 2004:3) and, ultimately, resilience in the face of our HIV-altered reality.

\section{ACKNOWLEDGEMENT}

The NRF are acknowledged for their sponsorship of the research reported on in this article. They are exonerated from any association with how the data/literature was interpreted.

\section{REFERENCES}

ADELMAN, H \& TAYLOR, L 2003: Rethinking school psychology (commentary on public health framework series). Journal of School Psychology, 41:83-90. http://www.puk.ac.za:2115/science/journal/00224405 (Accessed on 2 June 2008).

BENNELL, P 2003: The Aids epidemic in Sub-Saharan Africa: Are teachers a high-risk group? Comparative Education, 39(4):493508.

BENNELL, P 2005: The impact of the AIDS epidemic on teachers in Sub-Saharan Africa. The Journal of Development Studies, April, 41(3):440-466

BHANA, D; MORRELL, R; EPSTEIN, D \& MOLETSANE, R 2006: The hidden work of caring: Teachers and the maturing AIDS epidemic in diverse secondary schools in Durban. Journal of Education, 38(2006):5-24.

BOLER, T 2003: Approaches to examining the impact of HIVIAIDS on teachers. http://www.aidsconsortium.org.uk/Education/ educationworkgroupseminars.html (Accessed on 9 July 2005). BOSCARINO, J \& DICLEMENTE, R 1996: Aids knowledge, teaching comfort and support for Aids education among school teachers: A statewide survey. Aids Education and Prevention, 8:267-277. http://www.springerlink.com/content/v346618334316471/ 
(Accessed on 9 July 2005).

CAMPBELL, B \& LUBBEN, F 2003: The provision of a health promoting environment for HIV/AIDS education: The case of Namibian senior secondary schools. http://www.sciencedirect.com/science (Accessed on 2 June 2008).

CAR-HILL, R 2003: The impact of HIV and AIDS on the teacher in the classroom. http://www.aidsconsortium.org.uk/Education/ educationworkgroupseminars.html (Accessed on 9 July 2005). CASTELLS, M 1998: Information technology, globalisation and social development. Paper prepared for the UNRISD Conference on Information Technologies and Social Development. 22-24 June, Palais des Nations, Geneva.

COOMBE, C 2000: Keeping the education system healthy: Managing the impact of HIV/Aids on education in South Africa. http:// www.tc.edu/cice/Archives/3.1/31coombe.pdf (Accessed on 9 July 2005).

COOMBE, C 2002: HIV/Aids and education. Perspectives in Education, July, 20(2):vii-x.

COOMBE, C 2003: Consultation on HIV/Aids and teacher education in East and Southern Africa. Paper presented at InWent, Kopanong Conference Centre, Johannesburg, 28-30 October. DAWSON, LJ; CHUNIS, ML; SMITH, DM \& CARBONI, AA 2001: The role of academic discipline and gender in high school teachers' Aids-related knowledge and attitudes. Journal of School Health, 71(1):3-8.

DE LANGE, N 2008: Visual participatory approaches to HIV and AIDS research as intervention in a rural community setting. Journal of Psychology in Africa, 18(1):179-188.

DE LANGE, N; MITCHELL, C; MOLETSANE, L; STUART, J \& BUTHELEZI, T 2006: Seeing with the body: Educators' representations of HIV and AIDS. Journal of Education, 38(2006):44-66. DoE See Republic of South Africa Department of Education.

DONALD, D; LAZARUS, S \& LOLWANA, P 2007: Educational psychology in social context; $3^{\text {rd }}$ edition. Cape Town: Oxford University Press.

EBERSÖHN, L \& ELOFF, I 2002: The black, white and grey of rainbow children coping with HIV/Aids. Perspectives in Education, 20(2):77-86.

ESTERHUIZEN, SM 2007: Critique of an intervention programme for educators affected by the HIV/Aids pandemic. Vanderbijlpark: North-West University (Unpublished MEd dissertation).

FERREIRA, R 2007: Community-based coping: An HIVIAids casestudy. (In: Duncan, N; Bowman, B; Naidoo, A; Pillay, J \& Roos, V eds. Community psychology. Analysis, context and action. Cape Town: UCT Press, pp 380-391).

FERREIRA, R 2004: Educational psychological intervention and therapy. (In: Eloff, I. \& Ebersöhn, L. eds Keys to Educational Psychology. Cape Town: UCT Press, pp 331-350).

GODINHO, J; JAGANJAC, N; ECKERTZ, D; RENTON, A\& NOVOTNY,
T 2005: HIVIAIDS in the Western Balkans. Priorities for early prevention in a high-risk environment. Washington: The World Bank. http://siteresources.worldbank.org/INTTSR/Resources/4626131135099994537/3401810HIVOAIDSOinOtheOWesternOBalkans.pdf (Accessed on 2 June 2008).

GOVENDER, P 2008: Teacher slammed for disclosing HIV status. Sunday Times, 20 April.

HALL, C 2004: Theorising changes in teachers' work. Canadian Journal of Educational Administration and Policy, 32:1-14. HALL, E; ALTMAN, M; NKOMO, N; PELTZER, K \& ZUMA, Z 2005: Potential attrition in education. The impact of job satisfaction, morale, workload and HIVIAIDS. Cape Town: HSRC.

HARTELL, CG \& MAILE, S 2004: HIVIAids and education: A study on how a selection of school governing bodies in Mpumalanga understand, respond to and implement legislation and policies on HIV/Aids. International Journal of Educational Development, 24:183-199.

HEAIDS 2007: Technical proposal: Piloting of HIV module in teacher education facilities in the higher education institutions in South Africa. August, WYG International Ltd.

HEAIDS 2008: Implementation planning. National colloquium on addressing HIVIAIDS within teacher education: Challenges and opportunities. 7-8 April, Benoni, Gauteng.

HOADLEY, U 2002: The regulation of teacher work identity: Core considerations. Journal of Education, 28:39-62.

HOADLEY, U 2007: Boundaries of care: The role of the school in supporting vulnerable children in the context of HIV and AIDS. African Journal of AIDS Research 2007, 6(3):251-259.

ICSW See International Council for Social Welfare.

INTERNATIONAL COUNCIL FOR SOCIAL WELFARE 1995: The Copenhagen consensus: A summary of principal commitments of the World Summit for Social Development, Copenhagen.

JACOB, WJ; MOSMAN, SS; HITE, SJ; MORISKY, DE \& NSUBUGA, YK 2007: Evaluating HIVIAIDS education programmes in Ugandan secondary schools. Development in Practice, 17(1):114-123. JOHNSTON, B 2005: Mental health promotion in Western Cape schools: An exploration of factors relating to risk, resilience and health promotion. Bellville: University of the Western Cape (Unpublished thesis).

KENDALL, N \& O'GARA, C 2007: Vulnerable children, communities and schools: Lessons from three HIV/Aids-affected areas. Compare, 27:5-21.

KINGHORN, A\& KELLY, MJ 2005: 'The impact of the AIDS epidemic' articles by Paul Bennell: Some comments. The Journal of Development Studies, April, 41(3):489-499.

KRETZMAN, JP \& MCKNIGHT, JL 1993: Building communities from the inside out: A path toward finding and mobilizing a community's assets. Chicago, III.: Acta Publications.

LE GRANGE, L 2008: Trends in educational research: South Afri- 
can perspectives. Paper read at the 2008 Research Seminar, Faculty of Education Sciences, North-West University, Potchefstroom, 28 February.

MATEO, R (JR); SAROL, JN (JR) \& POBLETE, R 2004: HIVIAIDS in the Philippines. AIDS Education and Prevention, 16(Supplement $A): 43-52$.

MATUBE, JM 2005: Impact measurement: Ithuba Trust grantmaking strategy towards poverty eradication and sustainable development. Pretoria: University of Pretoria (Unpublished DPhil thesis). MIDGLEY, J 2001: South Africa: The challenge of social development. International Journal of Social Welfare, October, 10(4):267-275.

MITCHELL, C; DE LANGE, N; MOLETSANE, R; STUART, J \& BUTHELEZI, T 2005: Giving a face to HIV and AIDS: On the uses of photo-voice by teachers and community health care workers working with youth in rural South Africa. Qualitative Research in Psychology, 2005(2):257-270.

MORROW, W 2007: What is teachers' work? Journal of Education, 41:3-20

NKINYANGI, S 2003: Reports of a consultation HIVIAids and education, 4-6 March, Kigali, Rwanda. Nairobi: UNESCO.

PATEL, L 2005: Social welfare and social development in South Africa. Cape Town: Oxford University Press.

PELTZER, K \& PROMTUSSANANON, S 2003: HIVIAids education in South Africa: Teacher knowledge about HIVIAids: Teacher attitude about and control of HIVIAids. Social Behavior and Personality, 31(4):349-356.

PRIDMORE, P \& YATES, C 2005: Combating AIDS in South Africa and Mozambique: The role of open, distance and flexible learning (ODFL). Comparative Education Review, November, 49(4):490511.

RAJ, A; DECKER, MR; MURRAY, JE \& SILVERMAN, JG 2007: Gender differences in associations between exposure to school HIV education and protective sexual behaviours and sexually transmitted disease/HIV diagnosis among high school students. Sex Education, 7(2):191-199.

REPUBLIC OF SOUTHAFRICA, DEPARTMENT OF EDUCATION 2000: Norms and standards for educators. Government Gazette No. 20844. Pretoria: Government Printer.

REPUBLIC OF SOUTHAFRICA, DEPARTMENT OF FOREIGN AF-

FAIRS 2004: African Union in a nutshell. http://www.dfa.gov.za/ au.nepad/au nutshell.htm (Accessed on 28 January 2008).

REPUBLIC OF SOUTHAFRICA, DEPARTMENT OF SOCIAL DEVELOPMENT 2005: Integrated Service Delivery Model. Pretoria: Government Printer.

REPUBLIC OF SOUTHAFRICA, MINISTRY FOR WELFARE AND POPULATION DEVELOPMENT 1997: White Paper for Social Welfare. Notice 1108 of 1997. Government Gazette, No. 18166. Pretoria: Government Printer.
SCHRATZ, M \& WALKER, R 1995: Research as social change. New opportunities for qualitative research. New York: Routledge. SCHULZE, S \& STEYN, T 2007: Stressors in the professional lives of South African secondary school teachers. South African Journal of Education, 27(4):691-707.

SHISANA, O; PELTZER, K; ZUNGU-DIRWAYI, N \& LOUW, JS eds. 2005: The health of our educators. A focus on HIV and Aids in South African public schools, 2004/5 survey. http:// www.hsrcpress.ac.za (Accessed on 9 July 2005).

SHISANA, O; REHLE, T; SIMBAYI, LC; PARKER, W; ZUMA, K; BHANA, A; CONNOLLY, C; JOOSTE, S \& PILLAY, V 2005: South African national HIV prevalence, HIV incidence, behaviour and communication survey, 2005. Cape Town: HSRC Press.

SIMBAYI, LC; SKINNER, D; LETLAPE, L\& ZUMA, K 2005: Workplace policies in public education. A review focusing on HIV and Aids. http://www.hsrcpress.ac.za (Accessed on 9 July 2005).

STUART, J 2004: Media matters - Producing a culture of compassion in the age of AIDS. English Quarterly, 36(2):3-5.

SWART, TM \& BOWMAN, B 2007: Activating action: Aims, methods and imperatives of research in community psychology. (In: Duncan, N; Bowman, B; Naidoo, A; Pillay, J \& Roos, V eds. Community psychology. Analysis, context and action. Cape Town: UCT Press, pp 432-449).

THERON, LC 2005: Educator perception of educators' and learners' HIV status with a view to wellness promotion. South African Journal of Education, 25(1):56-60.

THERON, LC 2007a: The health status of Gauteng and Free State educators affected by the HIV and AIDS pandemic - An introductory qualitative study. African Journal of Aids Research, 175186.

THERON, LC 2007b: Uphenyo ngokwazi kwentsha yasemalokishini ukumelana nesimo esinzima: A South African study of resilience among township youth. Child and Adolescent Psychiatric Clinics of North America, 16(2):357-375.

THERON, LC 2008: "I have undergone some metamorphosis!" The impact of REds on South African educators affected by the HIV/ Aids pandemic. A pilot study. Journal of Psychology in Africa, 18(1):29-40.

UNESCO \& EI-EFAIDS 2007: Supporting HIV-positive teachers in East and Southern Africa. Technical consultation report, 30 November - 1 December 2006, Nairobi, Kenya. Paris: UNESCO.

WINKELMANN, CV 2006: Sex education between state and socia organisations - An example from North-Rhine Westphalia, Germany. AIDS 2006 - XVI International AIDS Conference: Abstract No. CDC1265.

XABA, I 2008: Workplace policies on HIV and AIDS. Guidelines for educators. (In: Resilient Educators. Unpublished research programme, pp 92-109).

ZAMMIT, A 2003: Development at risk: Rethinking UN-business 
partnerships. [SI]: South Centre \& United Nations Research Insti-

tute for Social Development. 